Int. J. Electrochem. Sci., 14 (2019) 10888 - 10906

International Journal of

ELECTROCHEMICAL

SCIENCE

$\underline{\text { www.electrochemsci.org }}$

\title{
Experimental Data Treatment of the Pipeline Steel Polarization Curve under AC Interference
}

\author{
Shouxin Zhang ${ }^{1}$, Zili Li ${ }^{1, *}$, Xinyi Su${ }^{2}$, Chao Yang ${ }^{1}$ \\ ${ }^{1}$ College of Pipeline and Civil Engineering, China University of Petroleum, No. 66, Changjiang West \\ Road, Huangdao District. Qingdao 266580, China \\ ${ }^{2}$ CNOOC Energy Development Equipment Technology Co., No. 867, Huayuan Industrial Zone. \\ Tianjin 300450, China \\ *E-mail: zilimenhuzu@163.com
}

doi: $10.20964 / 2019.12 .05$

Received: 13 June 2019 / Accepted: 16 August 2019 / Published: 29 October 2019

The treatment of polarization curves of pipeline steels subject to AC (Alternating Current) was studied. The Tafel exploration, the non-linear curve fitting method, and the SYMADEC (synthesis, matching, and deconvolution of polarization curves) algorithm were used to evaluate the Tafel slopes and the corrosion current density from a set of experimental polarization curves. The results of the Tafel exploration show a large variation when different linear portions were selected for the calculation. The non-linear curve fitting method is sensitive to noise and easy to fail when used to fit planarization data presenting AC signal. SYMADEC is a robust method to fit the experimental polarization curves, which do not present a Tafel region. Moreover, the results of SYMADEC can be deconstructed into the anodic and cathodic components providing more kinetics information about the electrode process. Therefore, in the study of the AC corrosion behavior by polarization curves exhibiting no Tafel region, the experimental data should be carefully treated to obtain accurate values of the kinetics parameters. The use of SYMADEC is recommended in this case.

Keywords: polarization curve; Tafel slope; corrosion current; AC corrosion

\section{FULL TEXT}

(C) 2019 The Authors. Published by ESG (www.electrochemsci.org). This article is an open access article distributed under the terms and conditions of the Creative Commons Attribution license (http://creativecommons.org/licenses/by/4.0/). 